\author{
Available online at JECE (Journal of Early Childhood Education) \\ Website: http://journal.uinjkt.ac.id/index.php/jece \\ Permalink/DOI: http://dx.doi.org/10.15408/jece.v2i2.18141 \\ JECE, 2 (2), Desember 2020, 170-182
}

\title{
FOSTERING PROSOCIAL BEHAVIOURS OF EARLY CHILDHOOD THROUGH GROUP GUIDANCE WITH A CLIENT CENTERED THERAPY APPROACH
}

\author{
Azmatul Khairiah Sari, Neviyarni, Yeni Karneli, Netrawati \\ Universitas Negeri Padang \\ Corresponding e-mail: azmatulkhairiah998@gmail.com
}

\begin{abstract}
This study aims to see how group guidance with a client-centred therapy approach in early childhood improves prosocial behaviour. This study uses library research method. Data analysis in this study used a narrative synthesis analysis. The results of this study indicate that prosocial behaviour is behaviour that is displayed when interacting with other people where children spontaneously help others. Prosocial behaviour is displayed by early childhood to the friends, parents, teachers and the surrounding community. Group guidance with a client-centred therapy approach provides counselling techniques to make early childhood become individuals who can understand their potential and actualize their social relationships. In the implementation of group guidance, early childhood will interact and communicate with each other; the counsellor can ask them to practice these prosocial behaviours. Either by answering questions if (...) then (...) or by telling how he should act when faced with a situation that requires displaying this prosocial behaviour.
\end{abstract}

Keywords: prosocial behaviour, early childhood, client centered therapy, group guidance

\begin{abstract}
Abstrak
Artikel ini bertujuan untuk melihat bagaimana bimbingan kelompok dengan pendekatan client centered therapy pada anak usia dini dalam meningkatkan tingkah laku prososial. Penelitian ini menggunakan metode library research. Analisis data dalam penelitian ini mengunakan analisis sintesis secara naratif. Hasil penelitian ini menujukkan bahwa tingkah laku prososial adalah tingkah laku yang ditampilkan ketika berinteraksi dengan orang lain dimana secara spontan anak menolong orang lain. Tingkah laku prososial ditampilkan anak usia dini kepada lingkungan sekitarnya baik itu teman, orangtua, guru dan masyarakat sekitarnya. Bimbingan kelompok dengan pendekatan client centered therapy memberikan teknik-teknik konseling dalam upaya membuat anak usia dini menjadi pribadi yang bisa memahami potensi-potensi dalam diri dan mencoba beraktualisasi dengan sosialnya. Di dalam pelaksanaan bimbingan kelompok, anak usia dini akan saling berinteraksi dan saling berkomunikasi, konselor bisa meminta mereka untuk mempraktikkan tingkah laku prososial tersebut. Baik dengan menjawab pertanyaan jika (...) maka (...) atau dengan menceritakan bagaimana ia harus bertindak ketika menghadapi suatu keadaan yang mengharuskannya menampilkan tingkah laku prososial tersebut.
\end{abstract}

Keywords: perilaku prososial, anak usia dini, client centered therapy, bimbingan kelompok 


\section{Introduction}

Early childhood is an individual who will develop many life skills. Early childhood needs guidance in growing their behaviour. Early childhood is a period where an individual will learn how they must prepare themselves for the future. Early childhood must learn skills that can make them independent and behave under the expectations of their environments.

As part of social beings, early childhood needs to show a prosocial behaviour to actualise appropriately with the surrounding environment (Siti Aisyah, 2010). When early childhood shows of prosocial behaviour frequently, he will be able to develop it appropriately. Prosocial behaviour is an essential value in developing social relationships with the community, but on the other hand, the community tends to influence early childhood prosocial behaviour. Early childhood still needs control in developing prosocial behaviour even though there are potentials for this prosocial behaviour.

During this period, an essential personality will become the milestones for one's identity as an adult (Ariani, 2019). This age is the golden age of a human life-span, at this time the child's brain development is at its peak which can support growth and development in various aspects, both cognitive, physical, motoric, social and emotional (Anamika, Devi, Marilyn Fleer, 2018). In social terms, a child will build interactions ranging from parents, siblings, playmates, to the broader community (Juni Dwi Riyanti \& Tim redaksi Cemerlang, 2013). Early childhood is experiencing very rapid development. The tasks and roles of the child's environment are prioritised in supporting development. Early childhood still needs guidance from the environment to shape their behaviour because it will be the future foundation.

Prosocial behaviour can be obtained from self-concept and the environment. Prosocial behaviour is an essential value in developing social relationships with the community, but on the other hand, the environment tends to influence early childhood prosocial behaviour (Mayangsari, Sari, \& Munaila, 2017). For example, a child who already has a self-concept helps his friend when the friend is in trouble; his prosocial behaviour will develop more because the environment also teaches the child.

Early childhood is critical because early prosocial behaviour usually tends to continue into the following years (Matondang, 2017). Prosocial behaviour is one of the fundamental developments that children must have because it is essential to prepare themselves to become group members in late childhood and adapt to the broader environment (Himmah, Faiqatul, 2013). The environment requires that early childhood have the right prosocial attitude to be applied in everyday life. 
The teacher is one of the environments that can grow early childhood prosocial behaviour at the school level. Teachers at the early childhood level will provide counselling guidance services. The importance of implementing counselling guidance at the early childhood level to provide understanding to children about the fundamental of behaviour. Social development is asked to form discipline, tolerance, altruistic attitude, and cooperative attitude in early childhood. Some of these attitudes are developed by organising programs that involve students in group activities. One of them is prosocial behaviour. The environment that foster early childhood prosocial behaviour is through the implementation of group guidance services. Through group guidance services introduced and carried out by students in groups, it will result in students having an objective (Addahri Hafidz Awlawi, 2018). In group guidance, children deal with values, building social skills, self-concept, and building academic skills (Hamdi, 2018).

Prosocial behaviour is related to social skills. By providing group guidance, it is hoped that early childhood children will have a proper understanding of prosocial behaviour and commit to carrying out prosocial behaviour in their daily lives.

The childhood level is an excellent first opportunity for educators to foster children's personalities to determine their future (Ice Aisah, 2012) Prosocial behaviour from the age of 4-5 years to 20 years of age concluded that prosocial behaviour was stable from early childhood to early adulthood (Santrock, 2007). Group members influence prosocial behaviour in the child's environment (Over, 2018).

As the child's closest figure, the teacher plays a role in laying the proper prosocial behaviour foundation. The right foundation will certainly be well developed by early childhood. If early childhood's basic prosocial behaviour is not appropriate, it will cause difficulties when entering the next development stage (Addahri Hafidz Awlawi, 2018). Providing group guidance services can put the foundations for early childhood prosocial behaviour to have pleasant social interactions. Group guidance services have many approaches to building prosocial behaviour in early childhood. One of them is the client-centred therapy approach. The groups to be formed using the client-centred therapy approach are personal growth groups, sensory awareness groups, sensitivity groups, and human relations groups (Adhiputra, 2015). Early childhood can be provided with group guidance services with a client-centred therapy approach because children are part of a personal growth group.

This study discusses how group guidance services with a client-centred therapy approach can build prosocial behaviour in early childhood. Client-centred counselling emphasises the counselee's ability to determine important things to the child and solve their problems. Client-centred counselling is carried out through a 
dialogue between counsellor and counselee to achieve a harmonious self-image between the ideal self and the counselee under the actual reality(Tanod, 2018). In implementing group guidance with a client-centred therapy approach, it is open to changes for the better. Early childhood who is still minimal about prosocial behaviour will change good prosocial behaviour.

\section{Method}

This research uses the library research method. In this study, data collection techniques include a review of books, literature, notes, and various reports. The literature search is more than just serving the mentioned functions to obtain research data. This research limits its activities to library collection materials without requiring field research.

This study's focus is aimed at children who have entered school age, namely at the kindergarten and early elementary school age. So that early childhood children who are given group guidance treatment can follow the instructions from the teacher.

The analysis stages in this study: first, by recording all the findings regarding prosocial behaviour in early childhood in general at each research discussion found in the literature and sources and group guidance services with a client-centred therapy approach. Second, combining all findings, both theory or new findings on prosocial behaviour and group counselling services, with a client-centred therapy approach. After that, analyze the sources of the reading and criticize the reading material.

\section{Result and Discussion \\ Early Childhood Prosocial Behaviour}

This article focuses on early childhood aged 6-8 years because they are already in school and regularly interact with other friends. Rogers, as the originator of ClientCentered Therapy, views early childhood as individuals who can develop positively. Early childhood can be positive with the abilities they have (Rita Eka Izzaty. Budi Astuti \&Nur Cholimah, 2017). Rogers did not see the core of human motivation as unfavourable: hostile, antisocial, destructive, or evil; nor as neutral, capable of being shaped into any form; nor as perfect in itself and corrupted only by an evil society (Fall, Kevin A. Janice Miner Holder, 2017).

Rogers views humans positively and gives a term for the individual, namely "self." "Self" has self-actualization and positive appreciation in itself (Khamim Zarkasih Putra \& Suyadi, 2016). Individuals have the potential to be healthy and grow creatively (Namora Lumongga Lubis \& Hasnida, 2016). Humans can be trusted and because they are cooperative and constructive (Namora Lumongga Lubis, 2011). 
Early childhood faces demands to be able to interact socially with their environment. At an early age, its development is well integrated both biologically, psychologically, and currently in social changes (Sudarwan Danim, 2017). Children will display the behaviour taught by their parents and their immediate environment. Parental love is the key to children's social development (Desmita, 2008).

Baron Byrne stated that prosocial behaviour is an act of helping others (Desmita, 2017). Prosocial behaviour is a form of behaviour that appears in social contact so that prosocial behaviour is an action taken or planned to help others regardless of the helper's motives(Desmita, 2017). Prosocial behaviour must be stimulated from an early age. Prosocial behaviour is undoubtedly useful, but of course, early childhood must know how he can build appropriate prosocial behaviour. Prosocial behaviour has six crucial things in its essence: sharing, cooperation, helping, honesty, generosity, and considering others' rights and obligations (Tinne RD, 2012).

Early childhood develops a behaviour to share how he feels and understand how others give him. Early childhood can express the sadness they feel appropriate to the environment around them. In general, early childhood will express their sadness by struggling, crying loudly, and even hitting the person who makes them sad, so when they understand how prosocial behaviour is appropriate, of course at least, they do not hit the person who makes them sad. Children will quickly stabilize their overflowing emotions. Building prosocial behaviour in the sharing dimension starts from the direction of the surrounding people. An environment that helps early childhood build how he can share his feelings appropriately(Riska Ochtoviana, Fakhriah, 2020).

The second essence of prosocial behaviour is cooperative behaviour. Early childhood is expected to build a sense of cooperation from an early age. Children are working together to complete a play, working together in making a solution to a difficult question. Then in working together, a child is required to be good at controlling the emotions he has. He must be tolerant of other friends' opinions when working together (Addahri Hafidz Awlawi, 2018).

Collaboration can also be trained through group guidance. The implementation of early childhood group guidance is taught to form a collaboration on the topic being discussed. With cooperation, the right prosocial behaviour can be started at an early age. Children who have good cooperation abilities can easily understand others' feelings, have excellent attention to their peers, and motivate others(Himmatul Farihah, 2017). Parents and teachers can seek to build prosocial attitudes about cooperation through group guidance. In group guidance, children will build a cooperative attitude to apply it in their daily lives. 
With cooperation, problems can be resolved by early childhood(Achmadi, 2017). Early childhood will develop prosocial behaviour to cooperate with the group to establish good communication and relationships with their environment.

Furthermore, prosocial behaviour that must be built in early childhood is helping. Helping is behaviour that is shown to help others; in some cases, the expected goals may not be achieved. Early childhood may not refuse to help others if they judge that it is morally right (Rizka Syifa Aminy, Rika Vira Zwagery, 2019) It helps other people, telling, offering help, or doing something that supports other people's activities. Therefore, early childhood behaviour should be developed to help the surrounding environment. Helping parents clean the house, helping friends in watering plants, or other things that we think are small but for early childhood is a big help for the environment.

Furthermore, another prosocial behaviour is honesty. Early childhood is the most honest individuals (Darma Kesuma, 2011). Early childhood should be given character education according to age development(Yasbiati, Mulyana, Rahman, \& Qonita, 2019). However, in its development, interacting with the surrounding environment causes early childhood to erode this honesty and make them less honest. So the surrounding environment must return early childhood to their nature as honest individuals. Implementing group guidance with a client-centred therapy approach makes the individual's potential not hidden and displayed appropriately.

Prosocial behaviour that needs to be built in early childhood is giving. Building an attitude of giving from an early age is expected to become less selfish and miserly adulthood. Several factors also influence prosocial behaviour in early childhood. The factor that most influences prosocial behaviour in early childhood is peers(Amini \& Saripah, 2016). The higher the peer prosocial behaviour, the child also has high prosocial behaviour. Then group guidance is held with peers so that early childhood can build prosocial behaviour from their friends in the group.

\section{Group Guidance with Client Centered Therapy Approach}

Group guidance is a type of guidance and counselling service organized in groups that includes several participants. Group guidance activates group dynamics to discuss various useful things for personal development and problem solving of participants in group activities (Prayitno, 2012).

Group guidance is held to provide personal, vocational, and social information. Counsellors provide group guidance services through small groups, and group guidance aims to respond to students' needs and interests(Mamat Supriyatna, 2011). So activities in group guidance are providing information for specific purposes for group members. 
Group guidance services refer to group activities that focus on providing information or experiences through planned and organized group activities(Robert L.Gibson dan Marianne H. Mitchell, 2011). Group guidance services strive to improve early childhood problems related to low prosocial behaviour through group guidance activities.

Client-centred therapy is a counselling technique where the most crucial role is the client himself; clients get an opportunity to find their solutions to their problems. This condition implies that clients are seen as partners and counsellors only as drivers and creators of situations that allow clients to develop independently (Corey, 2003). Client-centred therapy allows clients to freely express their problems, feelings, and thoughts. This approach also says that someone who has a problem still has potential and can solve the problem on his own (Prayitno\&Amti, 1994).

Group guidance services allow group members to collectively obtain materials and opportunities from group leaders and fellow members, to discuss various topics that are very useful for decision consideration. However, because the group members are early childhood, the group leader must be active. The group leader must often catch the messages conveyed by early childhood who are members of the group.

In group guidance, group dynamics are developed, controlled, and utilized to achieve guidance and counselling goals. Group guidance services are oriented towards developing insights, knowledge, skills, values and attitudes towards the content of the topics discussed. Group guidance is intended to respond to and meet the needs and interests of service members. The issues addressed in this group guidance are common problems and not a secret, such as study habits, prosocial behaviour, increasing self-confidence and many other group guidance topics(V.S Wikarta, 2016).

Besides being able to produce good relationships among group members, communicate between individuals, understanding various situations and environmental conditions, it can also develop attitudes and concrete actions to achieve desired things as revealed in the group.

Group guidance intends to discuss specific topics. Through intensive group dynamics, discussing these topics encourages developing feelings, thoughts, perceptions, insights, and attitudes that support more effective behaviour (Lestariani, 2014). With the guidance of early childhood groups, children can develop prosocial behaviour. Because group guidance also trains how group members interact and socialize with other group members.

Group members are also expected to have prosocial behaviour that can be applied in everyday life. The purpose of group counselling services is to take 
advantage of group dynamics to change group members' behaviour. Through the group dynamics that develop, each group member gives each other suggestions, ideas and opinions, ideas for developing the behaviour (Addahri Hafidz Awlawi, 2018).

There are three functions of group guidance services, namely (1) informative function, (2) development function, and (3) preventive and curative function (Sukardi, 2000). So the process of carrying out group guidance for early childhood is to provide the necessary information and knowledge for children about how to behave in the right prosocial manner so that children can become members of groups that develop proper prosocial behaviour in everyday life when interacting with friends. The guidance group hopes that they will prevent and minimize the development of children's inappropriate prosocial behaviour.

For the implementation of group guidance, some stages must be carried out by the group leader. These stages are what will be passed in group guidance. This stage is an integral part of all group activities; then, various experts have identified the steps of group guidance activities. They use terms that are sometimes different but have the same content.

In the group guidance stage implementation, it is necessary to consider members who can be united. Early childhood is also invited to follow the stages in this group guidance. However, later group leaders will be more active in directing early childhood to focus on group leaders' group guidance.

Group leaders can facilitate a sense of trust by separating positive and negative feelings from group members (Adhiputra, 2015). The group leader will direct group members regarding the stages of implementing group guidance. The group leader strengthens a positive feeling so that child, as an individual, can perceive it as part of his self-concept and develop this prosocial behaviour.

Group guidance with a client-centred therapy approach is centred on individuals with the concept of self-realization growth (Rosada, 2015). Group guidance using a client-centred therapy approach also helps manage behaviour changes from unpleasant to pleasant (Wikarta, 2016). By providing group guidance with a client-centred therapy approach, it is hoped that early childhood children will build prosocial behaviour which becomes the basis for them to interact with their surroundings later.

\section{Improving Pro-Social Behaviour through Client Centered Therapy Group Guidance Services}

The steps for implementing client centred therapy group guidance are:

1. Milling around, the initial stage of a group meeting. At this stage, it starts with confusion which causes them to be frustrated, silent, and a tendency for small 
talk. The group leader invites early childhood to talk casually but is still following the norms of implementing group guidance. The group leader invites the atmosphere to accept what group members are.

2. Resistance, members begin to enter groups with private themselves and publicprivate. They tend to avoid exposing themselves. At this stage, the group leader must show empathy and invite group members to accept other group members as part of it. Encourage early childhood to accept friends as people he can talk to freely and openly.

3. Revealing Past Feelings, trust begins to arise, and members have started to open up about their feelings and the past. Group members often act as if what is said has something to do with the present, even though that rarely happens. Group members state problems with prosocial behaviour in their daily life.

4. Expression of negative feelings, an expression of negative feelings directed at the group leader. For example, he was angry because his friends asked him to give his food to the group leader. He was annoyed that his friend had asked him for help. All these feelings will be shown by early childhood to the group leader.

5. Expression of Personally meaningful material, at this stage, members begin to believe in the group and feel free to talk about meaningful events in their lives. At this stage, early childhood trust will arise in his friends in the group to openly convey what is on him about his prosocial behaviour. The group leader must still provide direction to the group members.

6. Communication of immediate interpersonal feelings, group members tend to express positive and negative feelings to their friends. At this stage, group members will express their displeasure with prosocial behaviour and do what they enjoy doing prosocial behaviour. Of course, other group members will respond to feelings conveyed by other friends.

7. Development of a healing capacity in the group, the members begin to feel conformity with their group friends, through their attention, understanding, warmth, care and support. Group members are directed to begin to be directed to identify their feelings, and there must be warmth from the group leader, and group members should also be trained in empathy. Group members give each other responses such as good prosocial behaviour carried out by early childhood so that children can have the empathy to carry out prosocial behaviour in their environment.

8. Self-acceptance and the beginning of change, the group members' self-acceptance begins to change. Early childhood as a group member begins to accept things that are not good in themselves concerning prosocial behaviour. The child tries to develop appropriate prosocial behaviour desired by the surroundings and does not harm him. The early childhood who usually does not want to help now is trying to help as best he can. 
9. Cracking of facades, the members tend to open themselves up naturally, removing their masks. In this stage, early childhood tries to present their selfconcept regarding their prosocial behaviour. He appeared all without being covered.

10. Feedback, group members receive constructive feedback, enriching group members to perceive how others see them. Group members are asked to provide feedback about the prosocial behaviour of other group members. From the perceptions of other group members, he could find out how other friends judged prosocial behaviour.

11. Confrontation, awareness of members to reach a climax. In this stage, early childhood confronts two negative things about prosocial behaviour to understand how to behave appropriately.

12. Helping relationships outside the group, resolving misunderstandings and developing new relationships. If the group understands that the prosocial behaviour is wrong, then the group leader will straighten out. The goal is that group members can find out whether their friends like their prosocial behaviour or not.

13. The basic encounter, members realize how satisfying and meaningful their relationships are. After he tries to express how his prosocial behaviour is in his friends' view, early childhood understood that the group's relationships are meaningful. There is a deep sense of empathy, so that early childhood learns from the group members how they try to be strong themselves and develop appropriate prosocial behaviour.

14. Expression of closeness, members express positive feelings about their experiences in group guidance and other people. Each of the group's early childhood conveyed what positive things they got from the group's guidance.

15. Behaviour changes, at the end of the group, there is a behaviour change. Members tend to be more open, honest, caring. Prosocial behaviour that is builtin group guidance should be practised by early childhood. The more often he practices, it will undoubtedly be his self-concept that a child is a person who has good prosocial behaviour (Wikarta, 2016).

There are no rules for group counselling with client-centred therapy. Clientcentred counselling helps clients who are helped to have a more mature personal (self) to manifest themselves (Prayitno, 2009). With the excellent personality possessed by early childhood, he will self-actualize well in the middle of the environment. Proper prosocial behaviour certainly causes children to self-actualize in their surroundings. 


\section{Conclusion}

Group guidance with a client-centred therapy approach offers the concept of solving client problems with their strengths. Group guidance with a client-centred therapy approach assumes that each client has good potential to be developed. Prosocial behaviour is an individual's ability to interact and help others selflessly. This prosocial behaviour will continue to develop following the stage of development of an individual. At an early age, this prosocial behaviour should have been developed. So that when he enters the next stage of development, he does not experience difficulties. The development of prosocial behaviour in early childhood can be done with group guidance using a client-centred therapy approach where this approach seeks to build and develop this potential positively and precisely.

\section{References}

Achmadi, A. (2017). Manfaat Kerjasama Dalam Kelompok Saat Bermain. Journal Of Early Childhood and Inclusive Education, 1, 64-73.

Addahri Hafidz Awlawi, E. Y. (2018). Jurnal KOPASTA Riau. 5(2), 111-119.

Adhiputra, A. A. N. (2015). Konseling Kelompok Perspektif Teori dan Aplikasi. Yogyakarta: Media Akademi.

Amini, Y., \& Saripah, I. (2016). Perilaku Prososial Peserta Didik Sekolah Dasar Berdasarkan Perbedaan Jenis Kelamin. Perilaku Prososial Peserta Didik Sekolah Dasar Berdasarkan Perbedaan Jenis Kelamin, 3(2), 222-230. https://doi.org/10.23819/mimbar-sd.v3i2.4384

Anamika, Devi, Marilyn Fleer, and L. L. (2018). We Set up a Small World': Preschool Teachers' Involvement in Children's Imaginative Play. International Journal of Early Years Education. 295-311. https:/ / doi.org/ doi:10.1080/09669760.2018.1452720

Ariani, F. (2019). Orang Tua Sebagai Penanam Nilai Pancasila Untuk Anak Usia Dini Di Era Digital. Journal of Early Childhood Education (JECE), 1(2), 60-68. https://doi.org/10.15408/jece.v1i2.12515

Corey, G. (2003). Teori dan Praktik Konseling dan Psikoterapi. Bandung: PT refika aditama.

Darma Kesuma, dkk. (2011). Pendidikan Karakter Kajian Teori dan Praktik di Sekolah. Bandung: PT Remaja Rosda karya.

Desmita. (2008). Psikologi Perkembangan. Bandung: Rosdakarya.

Desmita. (2017). Psikologi perkembangan Peserta Didik. Bandung: PT Rosda Karya.

Fall, Kevin A. Janice Miner Holder, \& A. M. (2017). Theoretical Models Of Counselling and Psychotherapy. New York: Routledge.

Hamdi, R. dan M. (2018). Bimbingan Dan Konseling Kelompok. Jakarta: Bumi Aksara.

Himmah, Faiqatul, F. Y. \& R. (2013). Perilaku Prososial Anak Usia Dini Di Sentra Bermain Peran Tk Al-Furqan Jember. INSIGHT, 9, 1-15. 
Himmatul Farihah. (2017). Mengembangkan sikap kooperatif anak usia dini melalui metode proyek. 3(58), 18-34.

Ice Aisah. (2012). Strategi Penumbuhan Perilaku Prososial Anak Usia Dini Melalui Metode Bercerita (Studi Kasus Di Pendididkan Anak Usia Dini (Paud) Matahari Rw X1V Kelurahan Citeureup Kecamatan Cimahi Utara Kota Cimahi). Journal of Chemical Information and Modeling, 1(2), 2252-4738.

Juni Dwi Riyanti \& Tim redaksi Cemerlang. (2013). Back To Nature, Mendidik $\mathcal{E}$ Mengasuh Anak Sejak Lahir Hingga Usia Sekolah. Yogyakarta: Andi.

Khamim Zarkasih Putra \& Suyadi. (2016). Bimbingan dan Konseling PAUD. Bandung: Rosdakarya.

Lestariani. (2014). Efektivitas Bimbingan Kelompok Melalui Media Permainan Playdough Untuk Meningkatkan Kreativitas. E-JOURNAL, 2(1).

Mamat Supriyatna. (2011). Bimbingan dan Konseling Berbasis Kompetensi. Jakarta: PT. Raja Grafindo Persada.

Matondang, E. S. (2017). Perilaku Prososial (Prosocial Behavior) Anak Usia Dini Dan Pengelolaan Kelas Melalui Pengelompokan Usia Rangkap (Multiage Grouping). EduHumaniora | Jurnal Pendidikan Dasar Kampus Cibiru, 8(1), 34. https://doi.org/10.17509/eh.v8i1.5120

Mayangsari, D., Sari, evi dwi novita, \& Munaila, N. (2017). Peningkatan Perilaku Prososial pada Anak Usia 4-5 Tahun Melalui Kegiatan Outbound Fun Estafet. PG-PAUD Trunojoyo, 4, 115-132.

Namora Lumongga Lubis. (2011). Memahami Dasar-Dasar konseling Dalam Teori Dan Praktek. Jakarta: Kencana Prenada media Group.

Namora Lumongga Lubis \& Hasnida. (2016). KOnseling Kelompok. Jakarta: Kencana.

Over, H. (2018). The influence of group membership on young children's prosocial behaviour. Current Opinion in Psychology, 20, 17-20. https://doi.org/https:/ / doi.org/10.1016/j.copsyc.2017.08.005

Prayitno. (2009). Wawasan Profesional Konseling. Padang: Universitas Negeri Padang.

Prayitno. (2012). Jenis Layanan Dan Kegiatan Pendukung Konseling. Padang: Universitas Negeri Padang.

Riska Ochtoviana, Fakhriah, R. (2020). 1) , 2) , 3). 5(1), 67-76.

Rita Eka Izzaty. Budi Astuti \&Nur Cholimah. (2017). Model Konseling Anak Usia Dini. Bandung: PT Remaja Rosda karya.

Rizka Syifa Aminy*, Rika Vira Zwagery, J. S. (2019). Perbedaan Perilaku Menolong Anak Usia Dini yang Diberikan Metode Cerita Moral yang Menekankan Emosi Positif Tokoh dan Metode Cerita Nonmoral di PAUD Idaman Banjarbaru. Kognisia, 2, 111-118.

Robert L.Gibson dan Marianne H. Mitchell. (2011). No Title. Yogyakarta: Pustaka Pelajar. 
Rosada, U. D. (2015). Model Pendekatan KOnseling Client Centered dan Penerapanya dalam Praktik. Bimbingan Dan Konseling.

Santrock, J. W. (2007). Perkembangan Anak Jilid 2. Jakarta: Erlangga.

Siti Aisyah, dkk. (2010). Perkembangan dan Konsep Dasar Pengembangan Anak Usia Dini. Jakarta: Universitas Terbuka.

Sudarwan Danim. (2017). Perkembangan Peserta Didik. Bandung: Alfabeta.

Sukardi, D. K. (2000). Pengantar Pelayanan Program Bimbingan dan Konseling di Sekolah. Jakarta: Rineka CIpta.

Tanod, M. J. (2018). Mareyke Jessy Tanod STKIP-PGRI Bandarlampung. 05(2), 85-96.

Tinne RD. (2012). Perilaku Sosial Ditelaah Berdasarkan Gender. Bandung: UPI.

V.S Wikarta. (2016). Pelaksanaan Konseling Kelompok dengan Pendekatan PersonCentered Therapy dalam Menangani Regulasi Diri Rendah Empat Mahasiswa Angkatan 2014 Prodi Bimbingan dan Konseling Fakultas Pendidikan dan Bahasa Unika Atma Jaya. Jurnal Psiko-Edukasi, 14(2), 125.

Wikarta, V. S. (2016). Pelaksanaan Konseling Kelompok dengan Pendekatan PersonCentered Therapy dalam Menangani Regulasi Diri Rendah Empat Mahasiswa Angkatan 2014 Prodi Bimbingan dan Konseling Fakultas Pendidikan dan Bahasa Unika Atma Jaya. Jurnal Psiko-Edukasi, 14(2), 125-142. Retrieved from http://ojs.atmajaya.ac.id/index.php/fkip/article/view/509

Yasbiati, Y., Mulyana, E. H., Rahman, T., \& Qonita, Q. (2019). Profil Kejujuran Anak Usia 5-6 Tahun di RA-At-Taufiq Kota Tasikmalaya. Jurnal Pendidikan Anak, 8(2), 99-106. https:// doi.org/10.21831/jpa.v8i2.28591 